\title{
The Problem of Being Black in Zora Neale Hurston's Color Struck
}

\author{
Hana Khalief Ghani ${ }^{1} \&$ Istbriq Talib Joody ${ }^{2}$ \\ ${ }^{1}$ College of Arts, Department of Translation, Al-Mustansiriyah University. \\ Email: h.horizons2013@gmail.com \\ ${ }^{2}$ College of Education for Women, Department of English Language, University of Baghdad.
}

Received March 3, 2017; Revised March 27, 2017; Accepted April 3, 2017; Published May 7, 2017.

\begin{abstract}
Human physical features such as skin color usually play an important role in defining who the person is. In many societies skin color contributes to determining social status and self-worth. This problems becomes more acute in case of women whose markers of beauty like having lighter skin mean she can enjoy more privileges in terms of partner choice, work, and status than women of dark skin. The present paper aims at exploring the impact of skin color on the life of Emma who is color stricken in Zora Neale Hurston Color Struck. Rather than discussing this issue in relation to the color-based discrimination by the whitedominated society against the black in Americ, the play focuses on the pernicious effects of internalizing the color-based feelings of inferiority among the black themselves. The paper argues that obession with one's skin color is not conduisve to one's well-being. Rather than happiness and empowerment, it leads to self-marginalization and life-long anxiety.
\end{abstract}

Keywords: Hurston, Color Struck, Emma, inferiority.

"Oh, them half whites, they gets everything"

\section{I-“I’m my own person”: A Look into Hurston's Life and Literature:}

Born in Notasulga, Alabama, on January 7, 1891 and spending the majority of her formative years in Eatonville, Florida, "the first incorporated black township in the United States and the setting for most of her fiction"(Oslica, Race, Class, Gender), Zora Neale Hurston (1891-1960) wrote in a time when "racism had proven relentless and oppression undaunting"(Cortez) From her early formative years in this city, Hurston was fully aware of the complexities of life black people in general, and black women in particular were facing. She was often troubled by threefold lingering question that keep haunting women in the black communities, namely; race, class, and gender. In her seminal study Rereading the Harlem Renaissance, Jones(qtd in Oslica, p.1) comments on the significance of these questions in Hurston's writings. She points out:

Not only does [her] work reveal[s] the complexities of tripartite race, class and gender relations, but [her life] and the challenges [she] faced as writer all call attention to the double jeopardy of being black and female in pre-Civil Rights movement America as [she] forged ahead in [her] desire to rewrite the American literary landscape.

(c) AesthetixMS 2016. This Open Access article is published under a Creative Commons Attribution Non-Commercial 4.0 International License (http://creativecommons.org/licenses/by-nc/4.o/), which permits non-commercial re-use, distribution, and reproduction in any medium, provided the original work is properly cited. For citation use the DOI. For commercial re-use, please contact editor@rupkatha.com. 
Hurston lives in a very traditional patriarchal black society which had fixed notions about gender roles and black women's position. In this society, the division of life into two distinctive sections: public and private proves to be gender-specific, i.e., the public life is the property of men and women are relegated to the invisible private sphere(Rose in Mitchell, 1989,173-174). This leads to the confinement of women to the world of domestic labor, child bearing and concomitant sexual activities(Case,1985, p.317).

Any discussion of Hurston's work should make use of her personal experience which she has recorded in her autobiography, Dust Truck on the Road (1942). In her autobiography, Hurston describes the dilemmas of her own people and the discrimination they confront within their communities. Even she grasps the nature of the taboos she violated, but she insists to present the truth about color prejudice and gender discrimination which is an open secret in a black life.

Hurston's mother Lucy Potts (1865-1904), was the pillar of strength that served to shape her child character. She helped her daughter with her schoolwork. She urged her to " Jump at de sun" , she felt that her daughter should be allowed freedom of imagination and behavior, therefore, she encouraged her creative impulses and the spirit of independence that later characterized her life(Patterson, 2005, p.15).

With the death of her mother Lucy in 1904, remarriage of her father, and maltreatment of her step-mother, "Hurston's joyful days ended and cruel reality began"( Laníková, 2007,p.17). She was forced, with her other oldest brothers, to leave home while the other four youngest children were spread among their mother's friends and family. The next ten years of Hurston's life were appropriately called "lost" by Butterworthy(2006) from the point of her career as a writer. Hurston calls the years, from 1904-14, her "haunted years," because her life was so dismal. She could not receive education for the lack of her father's money and had to work in order to maintain herself.

At the age of sixteen Hurston joined the Gilbert Sulliven theatre company as an actress' maid. This was a great opportunity for Hurston to travel and first of all get independent. In spite of the fact that the members of the company were of various nationalities, colors of skin and social classes, there were no disputes or racial problems(Butterworthy, 2006). The only things that mattered were skills and abilities of each member(Hurston, 1995). She never felt discriminated which would later affect her position towards the subject matter of her books. In a letter to Constance Sheen in 1926, Zora wrote: " you know how interesting I am in theater and I am just running wild in every direction trying to see everything at once"(qtd in Kolin, 2007, p.12). In her published and unpublished plays, as well as her work as actress and director ,Zora stressed social ritual and the verbal arts to capture the experience of black people in folkloric humor and pastoral life(Ibid., p.13).

The sense of independence is very important for Hurston the writer and the woman. It enabled her to subvert the stereotypical images and roles usually assigned to women in her time. Her independence is reflected not only in her literary career, but also in her life style. Her being an anthropologist, novelist, folklorist, memoir and short story writer, essayist and a journalist testified to her intellectual ambition, while smoking cigarettes in the street, wearing pants and a tie, driving the car for long distances alone, and preferring a divorce and loneliness to abandoning her career which were "unbelievable for a woman in the 1930s," and ran contrary to what "a black woman was supposed to be" reveals Hurston's new consciousness of what a woman should do in order to survive in this rapidly changing world. Hurston was an independent woman at a time when the personal price for such self-expression was high(Bengal, 2010). 
Hurston criticizes the elites who encouraged the Migration from the rural south to the urban north. The Great Migration, according to her, has violent and devastating results to those who are left behind, especially for black women who couldn't cope with the social mainstream there. Being both black and female diminish their opportunities to work in the big cities of the north. She herself acknowledged in her autobiography Dust truck on the Road that her life " was in danger several times, if I had not learned how to take care of myself in these circumstances, I could be maimed or killed on most any day of several years of my research work"(Hurston, 1996, p..146) .

Dust Truck on the Road also documents her work experiences and how race and gender relations came into play in her employment. While in Florida, she finds a job as servant for a white family . An older black male, already working there, views Hurston as a threat in many ways. Hurston's experience thus reveals intraracial, as well as interracial, conflicts. She also works for other white families and individuals in a variety of contexts. In another servant job, the husband takes an interest in Zora, making her feel uncomfortable, he wants to run away to Canada with her. This shows the vulnerable position of black females in relation to white men(1996, p.156). This episode can be traced back to white male- black female relationship in the South, when AfroAmerican female slaves found themselves viewed as sexual property by the white male slave owners, who had position of power and authority over them(Jones, 2009, p.39).

Closely connected with the question of gender is the question of color bias,i.e., to judge people on the bases of their skin color or hue. In her widely anthologized descriptive essay "How It Feels to Be Colored Me", Hurston gives an autobiographical account of "the very day that [she] became colored."At the beginning of the essay, Hurston delves into her childhood in Eatonville, Florida, where she viewed herself as "everybody's Zora," free from the alienating feeling of difference. She is not aware of the racial division that exists outside of her world. However, as she left home at the age of thirteen to attend a boarding school in Jacksonville, she immediately became "colored."After realizing that she is of color, Hurston develops an extended metaphor in which she fosters a perspective that looks beyond pride in one's race to pride in one's self. In fact, Hurston never really places a significant emphasis on the racial inequalities that exist in America. This can be observed in many of her other works as well. It is worth mentioning that Hurston's father himself is a light-skin man(Banks, 2000).

Colorism, a term coined by Alice Walker in 1982, or discrimination based on skin color is a form of prejudice or discrimination in which human beings are treated differently based on the social meanings attached to skin color. According to The Association of Black Psychologists, Colorism is skin color stratification. It is "a form of oppression that is expressed through the differential treatment of individuals and groups based on skin color. Typically, favoritism is demonstrated toward those of lighter complexions while those of darker complexions experience rejection and mistreatment"( Bhattacharya, 2012, p.5). Colorism, or skin color stratification, is a process that privileges light-skinned people of color over dark in areas such as income, education, housing, and the marriage market. It directly related to the larger system of racism in the USA and around the world(qtd in On Dark Girls).

The effects of colorism may be observed in Black women's self-perceptions, ethnic identity, relationships, men, mate selection, family dynamics, educational and occupational outcomes, income levels, and mental and physical health(On Dark Girls, p.2). Although more positive images and role models for African American women are beginning to emerge, the stereotypes emanating from slavery simply mutate with time, creating newer versions of the same theme that continue to influence the sense of self of Black girls/women. Besides economic 
opportunity, education, and Risk Behaviors, the most important effects of colorism are selfesteem and perceptions of beauty.

Skin color, moreover, can affect how black women are judged by other black people. Because appearance is often central in the evaluation of women, the effect of colorism on selfesteem and well-being is stronger for African American girls and women compared to males. Adolescent girls and women are at greater risk of self-objectification reinforced through constant societal messages and public images emphasizing the physical appearance of women and girls. For African American girls, self-objectification may appear as a preference for physical characteristics they believe will be judged more favorably (i.e., lighter skin, longer hair, keen features, fine hair texture, etc.). This may pose a particular risk for African American girls who may not conform to this standard. Wingood et al.,for example, found that African American girls, who judged their physical appearance negatively, felt they had less personal control over choice of their partners(On Dark Girls, p.2).

Color, therefore, as power, was a determining factor as to who achieves success, position, and recognition. Lighter skin color almost always signifies beauty and marks one as of higher class. While darker skin refers to ugliness and always ranked as lower class(Patterson, 2005,p.104). Konzett(2002, p.94) states that : "those with white blood (mulattoes) are considered to be socially, culturally, and/or biologically superior."

These feelings about color had its roots in centuries of racism and miscegenation, and it found its way into the social relations between men and women and the social structure as a whole. Calling someone black was a deliberate insult, and commenting about size, especially directed at women, compound the injury. This scornful attitude toward black women receives mouth sanction by black male; in their notions, they consider darker skin women evil. They claimed that:

black women brought bad luck for a week if they came to your house on a Monday morning. They slept with their fists ballad up ready to fight and squabble even while they were asleep. They even had evil dreams. White yellow or brown girls dreamed about roses, perfume, and kisses. Black gals dreamed about guns, razors, ice picks, hatchets and hot lye.(qtd in Patterson, 2005, p.112)

This notion embodies a view of gender by black males. By nature black women were affected by such view, they believed that lighter skin women had more opportunities and prestige and they were apt to marry.

In her works, Zora tried to change this view, she studied the black people on their own terms, in her writing she focuses on the discrimination within the community itself. She presents race in term of social drama that is enacted or experienced, rather than as a formalized sociological process(qtd in Patterson, 2005, p.7). For her, race becomes a "complicated cultural construction rife with contradictions and multiplicities". Moreover, she reports that "At certain time I have no race, I am me ... I belong to no race nor time. I am the eternal feminine with its string on beads"(qtd in Konzett, 2002, p.84).

Hurston acknowledged discrimination and violence is a fact of life not only in the Jim Crow society but also inside black community. Many of her contemporaries dared not tread in this terrain for fear of undermining the struggle against racist violence. Hurston was able to confront black male sexism and violence toward women and criticized black male leadership. Through her writing she examines the ways in which gendered spaces were contested in black community, how race often took a back seat to class, and how color nevertheless remains a 
salient factor in daily life. This was bold position at a time when white violence against black people was destroying thousands in both the North and the South(Patterson, 2005, p.92).

Moreover, unlike many of Harlem literary figures who linked art to racial and social reform when they used it as a medium to portray the injustice suffered by Afro-Americans, and focused so narrowly on the horrors of the Jim Crow in black southerners' lives, Zora as a member of the "New Negro Movement" sought instead to present more positive and active image of black culture to white America. She thought this could contribute to a much better understanding between blacks and whites. In her view she saw that a history of domination and oppression needs to be obscured and forgotten at least momentarily, so as to bring forth one of action, vitality, and consummation that they believed would retrieve the negro from social death(Patterson, 2005, p.12) .This may account for the unfavorable criticism her works received from Richard Wright, one of the leading figures in the Harlem Renaissance of the thirties, and Wallace Thurman, Hurston's contemporary and a founder of Fire! Magazine(Laníková ,2007,p.26).

\subsection{Emma(color)line or the Girl who cannot Cross the Line in Hurston's Color Struck:}

Hurston's Color Struck explores the dilemma of Colorism and its consequences on a young black lady. It is generally agreed upon that Colorism operates both intraracially and interracially. Intraracial colorism occurs when members of a racial group make distinctions based upon skin color between members of their own race. Interracial colorism occurs when members of one racial group make distinctions based upon skin color between members of another racial group.(Herring, 2004, p.3). Hurston's play focused on intraracial colorism specifically within the Black community.

'Color Struck' according to North is "a term for Emma's obsession but also for retreat it causes"(1994, p.175). Yet, the term "color struck" was popularized by Hurston at a party after the 1925 Opportunity awards dinner when she comes in and "[triumphantly cries], "Calaaaahstruuuck." North interprets such triumph that Hurston imbues in the cry as what she intended to do with the play. North also points out the historical background of the cakewalk, highlighting its minstrelsy origins; he writes "the cakewalk [is] a cliché of black life"(Ibid.)

Emmaline, the play protagonist, is black, poor, rural, woman, believes that her darker skin disqualifies her for love. Emma is very black indeed, too black for her own comfort, her color consciousness causes her alienation from other people, including her lifelong love, John who is himself "A Light brown-skinned man" as the stage direction tells.

Hurston consolidates Emma's feelings of alienation and self-dislocation by a number of elements which confront the audience in the very opening lines of the play. The question of Colorism figures out very clearly in the title itself. The choice of the protagonist's name is quite significant. Throughout the play, and even in the stage directions, she is Emma. However, the 'line' which is attached to her name in the introduction of the dramatis personae tells of the insurmountable color line which she cannot cross. This line signifies an ongoing process of internalization of racial and stereotypical images. Moreover, it is noteworthy that the opening scene takes place on a Jim Crow railway car in Jacksonville, Florida; a clear reminder of the long history of racial discrimination and oppression. The late arrival of John and Emma and their quarrel because of Emma's morbid jealousy betrays Emma's feelings of inner insecurity and her failure to overcome her obsession with the dark color of her skin. Besides, in stark contrast to the movement of the railway coach which is advancing forward, Emma is moving backward throughout the play till she is left alone lamenting her miserable life in the closing scene. 
Emma's black color obsession results in an inferiority complex which is manifested not only in self-depreciating behaviour but also contributes to determining her place and identity. In the apt words of Lillie Howard : "the play examines how one dissatisfaction with one's color can lead to inferiority complex which undermine one's entire life"(qtd in Jones, 2009, p.24). Thus the play not only concentrates on color bias and self-pity, but also on fragmented identity and inner dislocation of the protagonist.

Color struck, set around 1900, is a play of four scenes, opened with a group of laughing, animated friends boarding on the Jim Crow railway car in Jacksonville, Florida, to participate in a cakewalk contest in St. Augustin. Upon their arrival, John claims that the reason behind their lateness is Emma's accusation that he was flirting with Effie:

EMMA (removing the hatpins from her hat, turns furiously upon him). You wuz grinning at her and she wuz grinning back jes lake a ole chessy cat. ${ }^{47}$

John denies this ,but Emma insists:

EMMA (about to place her hat in rack).You wuz.I seen you looking jes lake a possum...Jes the same every time you sees a yaller face, you takes a chance (Hurston, 2008, p.37)

'Yaller, yeller or High yellow' is key term here. Besides reflecting the long history of color-based classification of people in the United States of America which dates back to the end of the 19th century and the early decades of the 2oth century, it determines how Emma looks at herself in relation to others. Emma here, as in other occasions, engages in what is called in sociology "between-group" social comparison. A process of self-evaluation which takes place through a continuous process of comparison with light-skinned girls is the root of Emma's dilemma(Farsides, 2012, p.16). The cakewalk as a sort of 'social competition' is a good chance to reveal one's inner potentialities and at the same time, one's place in terms of skills and capabilities. Although the prospects of John and Emma's winning the contest is high because they "the bestest cakewalkers in dis state", Emma's jealousy and self-hate plays a major part in making her lose this chance to the'Yaller' girl Effie who wholeheartedly agrees to dance with John.

As a girl, Effie gains privileges because of her light skin and descent from white ancestry. Unlike Emma, Effie, 'the mulatto girl' is fully aware of "her worth, both economic and sexual, she is aware of her looks and of how prized her light brown skin is."(Beneš, 2011, p.61) The timing of Effie's entrance into the coach before John and Emma, and the wholehearted welcome and immediate admiration she receives from a member of the opposite gender reflected how deeplyseated the color-bias is in Emma's community. “Howdy do, Miss Effie, you'selookin' jeslak a rose. Fack is, if you wuzn'twalkin' long, ah'd think you wuz a rose". Comparing Effie to a rose confirms the fact that she is "both admired for and aware of what her skin color and her looks entail"(Ibid.). In this sense, physical attractiveness for Effie becomes a source of empowerment and a good economic and social asset.

In spite of John's continuous denials of flirting with Effie, his flirtation with the latter for the second time enforces Emma's belief that john is really obsessed with Effie. When one of the characters asks Effie to dance without a partner, "John applauds loudly" and says: " if dat Effie can't step nobody can". Emma's following comment betrays her inner nervousness and jealousy" Course you'd say so cause it's her. Everything she [Effie]do is pretty to you."( 1-37), John tries in vain to comfort Emma and to point out the stupidity of her behaviour saying "Emma, what makes you always picking a fuss with me over some yallergirl. What makes you so jealous, nohow ? I don't do nothing.(1-38) 
This question is the base of the conflict in Color Struck. It is crystal clear that Emma is consumed by jealousy which causes her alienation and ultimate destruction. As in the case of Othello in William Shakespeare's Othello, jealousy in the play works as "the green-ey'd monster, which doth mock The meat it feeds on."(Act3, Scene3) But Emma "can't help [her]selffrom being jealous. [She] loves [John] so hard, and jealous love is the only kind [she] got." (1-39)

The second scene took place outside the dancing hall, just before the cakewalking contest. It was informed that a couple who win the contest will travel up to the north. All the partners were happy, except Emma who remains reticent and suspicious. John again tries to set her at ease, he tells her:

You certainly is a ever loving mamma-when you aint mad.

EMMA (smiles sheepishly). You oughtn't to make me mad then.

JOHN. Ah don't make you! You makes yo'self mad, den blame it on me. Ah keep on tellin' you Ah don't love nobody but you. Ah knows heaps uh half-white girls Ah could gitef Ah wanted to. But (he squeezes her hard again) Ah jus' wants you! You know what they say! De darker de berry, de sweeter de taste!(2-41)

The connotation of John's "De darker de berry, de sweeter de taste!" is twofold. On one hand, John apparently means to say that Emma is really sweat and that the darker she is, the sweeter she becomes. It is an early invocation of the slogan "The Black is Beautiful" which gains in importance in the USA during the tumultuous 1920s. It was part of the black cultural movement's efforts to counteract the prevailing idea in the dominant American culture that features typical of "Blacks" were less attractive or desirable than those of "Whites". It is generally agreed upon that the idea of "blackness" being ugly is highly damaging to the psyche of Afro- Americans, manifesting itself as internalized racism(Carpenter, 2009. p.22). On the other hand, John's statement calls into mind a similar situation suffered by the protagonist of Wallace Thurman's The Blacker the Berry: A Novel of Negro Life (1929), Emma Lou Morgan, who also falls victim to the color-bias and discrimination practiced by lighter-skinned Afro- Americans due to her dark skin. However, while Thurman's Emma learns to come to terms with her skin color in order to find satisfaction in her life, Hurston's Emma fails to cross the line of colorism and spends her life imprisoned inside a cocoon of her own making.

Emma's jealousy is revealed in another incident which intensifies her suspicion of John's affection for Effie. Sitting opposite to each other in the coach, Effie offers a piece of pie to John and Emma. Though he knows it will upset Emma, John's acceptance of the piece makes Emma more confused:

EFFIE. Y'll have a piece uh mah blueberry pie -it's mighty nice! (She proffers it with a timid smile to Emma who "freezes" up instantly.)

Emma. Naw! We don't want no pie. We got cocoanut layer-cake.

JOHN. Ah-Ah think ah'd choose a piece uh pie, Effie. (He takes it.) Will you set down an' have a snack wid us? (He slides over to make room.)

Emma again stressed the same idea that obsessed her:

Naw, youse jus' hog-wile ovah her cause she's half-white! No matter whut Ah say, you keep carryin' on wid her.(2-41) 
According to Bower, Emma is an exemplar case of the "damaging consequences of an obsession with skin tone among Blacks." The consequences of being "color struck" that one sees throughout the play is escalating anger, low self-esteem, paranoia, and schizophrenia. Bower also points out, Emma does not show animosity towards segregation, but rather is angered by the intra-race hierarchy. Because of Emma's "psychotic obsession with color", she is unable to truly be happy, love, overcome oppression, and consequently is "the only miserable character." Such obsession is self-destructive, distorts vision, and has the possibility of ruining opportunities(Bower, 2004, p.729)

Emma, as a woman of color, is uneducated yet knowledgeable to her limits. Krasner suggests that "Emma's darker hue and the social condition that are imposed on 'blackness' makes her a subject to exclusion both externally and internally"(qtd in Kolin, 2007, p.19). In fact, Emma's femininity, blackness, poorness, and powerlessness lead her to psychological dislocation. Her extreme reaction emerged from her extreme condition. The loss of her lover is translated to a sense of disowning and homelessness that leads to a condition of extreme anguish, which, in turn, creates instability and a detachment from others(Konzett,2002, pp.95-98).

In Black Rage, the psychiatrists William Grier and Price Cobbs point out that "femininity, as it is defined in the time of writing Color Struck, is something she [the black woman] cannot achieve"(qtd in Crawford, 2008, p.17). This is one of the reasons that makes Emma herself practice what is called anti-black racism against herself.

Emma's constant state of jealousy and her fear from the possibility of travelling to the north if she and John win the contest cause her rejection to participate in the cakewalk contest; a decision that makes John take Effie as his partner. Instead of Emma "Miss Effie Jones will walk for Jacksonville with Mr. John Turner in place of Miss Emmaline Beazeley". In her rage Emma reports that: "Oh-them yaller wenches! How I hate em! They gets everything they wants."(2-42)

John's quick choice of another dancing partner means, Beneš (2011, pp.59-60) asserts, that Emma is dispensable to him. Moreover, Emma feels that her possible social uplift is hindered by the light-skinned people, such as Effie, who tend to get the jobs inaccessible to dark black people. Emma thus feels like a mule, now that her fears finally surfaced and came true. Her dark berry and fried chicken are not enough for John, he wants to pick lighter berries from the basket of a light skinned girl. Emma summarizes her desperation and powerlessness - which are then to be highlighted in the next scene - in the metaphor of the mule; a metaphor Hurston will use in her other works as well.

Beneš(2011, pp.59) also believes that Emma is very gender- and class-conscious, fearful of her own black body and its sexual power, and she is aware of the ways other people perceive her. Emma's last words in scene two, which take the form of soliloquy, epitomize her conviction of discrimination within the black community which leads to the privilege of light-skinned blacks over dark-skinned blacks:

Emma: A,!Mah God! He's in there with her-Oh, them half whites, they gets everything, they gets everything everybody else wants! The men, the jobs-everything! The whole world is got a sign on it. Wanted: Light colored.Us blacks was made for cobble stones. (She muffles a cry and sinks limp upon the seat).(2-44)

In these words, Emma summarizes the condition of black women as nothing more than cobble stones for others to walk on. After the soliloquy, Emma ends up humiliated and alone on the stage. 
In the third scene, a man declares that Effie and John have won the cakewalk. Emma stands outside alone, listening to the announcement, all the people inside were enthusiast, and happy, while Emma is melancholic. This moment is the most theatrical one in the play. As a sensitive writer Hurston presents a highly theatricalized description of the stage action:

Emma springs to her feet and flings the curtains wide open. She stands staring at the gay scene for a moment defiantly then creeps over to a seat along the wall and shrinks into the Spanish Moss, motionless.(3-44)

The juxtaposition is extreme: Emma is motionless and silent, while all the others, who were not afraid to show their skin onstage, dance together for seven to nine minutes. Emma's inability to speak up and be heard when she needs this ability the most is striking, and it underscores the importance of silence or voicelessness for Hurston's artistic and political agenda. Emma is here both color-struck (blind) and mute, which are signs of resignation and powerlessness(Beneš, 2011, p.58).

By rejecting her own skin; at an event that signifies racial pride, Emma opts to relegate herself into a marginal position, and as a result pays dearly by being left alone ${ }^{61}$. Emma "has decided not to compete rather than risk subjecting herself to a prejudicial slur"(qtd in Beneš, 2011, p.58). She isolates herself, though she does not stop watching the dance scene, hurting and confirming her darkest nightmares about both self and John's lust. In this way, she "internalizes a sense of racial inferiority." There is not much speaking in this scene; it is rather a dance performance, which serves to highlight John's achievement in contrast to Emma's isolation(Ibid). And so while Emma watches motionless, Effie takes the arm that John offers her and they parade to the other end of the hall. She takes [Emma's] place.

Being thrown to the moss summarizes Emma's being thrown from house, home, and community. Her fragmented soul, losing identity, and agonized situation separated her from any type of sound self-conceptualization. Lying there in silence shows the complexity of Emma's social circumstances arising from disengagement with reality itself. Emma" bespeaks a tragedy beyond words"(Konzett, 2002, p.97). She's suffering self-alienation. Hurston's eloquent style and mastery of language make her use silence as a strong way of expression.

Although twenty years have passed since the audience saw Emma, the final scene of the play brings nothing new about her. The scene takes place in Emma's house "a one-room shack" into which "some light enters through the window and falls on the woman seated in the low rocker. [...] As the curtain rises, the woman is seen rocking to and fro in the low rocker. A dead silence except for the sound of the rocker and an occasional groan from the bed"(4-46). The occasional groan here is the groan of Lou Lillian, the illegitimate daughter of Emma by a white man.

Practically speaking, nothing has changed in Emma's. She is still motionless, silent, lonely, and surrounded by darkness. John returns in search for Emma. From the beginning of this scene Hurston refers to Emma as "a woman", by doing so, Hurston suggests that Emma's isolation is a symbolic representation of black woman in the south which confronted such kind of selfcontempt and fragmentation.

John claims that he lived "up north" and was married for seventeen years and now he is widower. Emma suggests that he married to a light skinned woman:

EMMA. Bet you' wife wuz some high-yallerdickty-doo.

JOHN. Naw she wasn't neither. She was jus' as much like you as Ah could get her.(4-46) 
The great irony of the play occurs when John finds out that Emma's daughter is a mulatto girl. Despite her past accusations it was she who bore a child with lighter-skinned man:

(He turns in his chair and Emma rushes over to the bed and covers the girl securely, tucking her long hair under the covers, too-before he arises. He goes over to the bed and looks down into her face. She is mulatto. Turns to Emma teasingly.)Talkin' 'bout me liking high-yallersyo husband musta been pretty near white. (4-47)

Emma told him that she has never been married. John looks forward to raising the daughter as his own, and having a family. Lou Lillian is very sick, and John sends Emma for a doctor. Emma will not go to a "colored doctor," and eventually goes to bring a white doctor. This means that Emma herself is unconsciously practicing color-based racial discrimination against her people. As she is about to leave, she comes back and sees John ministering to her daughter:

JOHN. It's all right, Emma. But our daughter is bad off-run out an' git a doctor--she needs one. Ah'd go if Ah knowed where to find one-you kin git one the quickest-hurry, Emma .

As Emma is about to leave, she hears John "Gee, she's get a full suite of hair ! Glad you did'nt let her chop it off. " (4-48)

Emma assumes that John is fascinated by her daughter because of her being half-white. In a rage, Emma attacks John and threatens to kill him, he struggles to free himself from her grip and exclaims:

JOHN (slowly, after a long pause). So this the woman I've been wearing over my heart like rose for twenty years! She so despises her own s] that she can't believe any one else could love it!. (4-50)

Emma can't believe anyone could love her, or could love her dark skin, because she herself, is a shamed of it. John leaves, and the doctor arrives. He is too late, and Emma's daughter is dead. The doctor remonstrates Emma for not having come earlier an hour would have made all the difference. When the doctor asks Emma "why didn't you come sooner" she replies: "Couldn't see".

As the doctor leaves, Emma is left on stage in a rocking chair staring at the door "a dry sob now and then".(4-50)

Emma's final words "Couldn't see", could have many interpretations . It may refer to Emma's inability to see her own hatred for her child because it reminded her of John's desires, and her complex of hating half-white skinned girls. Or she couldn't see the fact that John was sincere to her, and when he urges her to go to the doctor, is just to save her child's life. Or she couldn't realize that her instability and self-contempt end up costing her the life of her daughter and her one true love.

Hurston chooses to close the scene with silence; Emma is rocking in her chair next to her newly dead child. The experience of sitting and observing her rocking is more theatrically basic and effective than dialogue. Emma spends her life blind to her own prejudice based on skin color, her racial insecurities cause her problem from the very beginning of the play right up to the end when she finally sits alone, sad at having lost everything. Tiffany Ruby Paterson, argues that Emma's "self-hatred and anguish is so deep that she destroys the love she so desperately yearns for"(Patterson,2005, p.92).

The image of Emma in fragments in the final moment onstage reveals Hurston's talent for documenting the social and psychological conditions of black women in the South. It also shows 
her talent for seamlessly inserting her thoughts and feelings into the fabric of her dramatic characters. Emma's isolation may be both a symbolic representation of black southern women and a personal experience drawn from the dramatist's life.

Although Hurston's biographer, Robert Hemenway, dismisses Color Struck as "not a very effective drama," because "on the whole, [it ] is an apprentice work [...] celebrat[ing] the proletariat"(Beneš,2011, p.59). Carpenter (2009, p.22) offers in her seminal article, "Addressing the 'Complex'-ities of Skin Color: Intra-Racism in the Plays of Hurston, Kennedy, and Orlandersmith" offers an insightful look into the play. She writes:

The topical significance of Color Struck is in how it challenges assumptions associated with color-consciousness. Rather than staging the color-complex as a unilateral dynamic in which light skinned blacks reject and separate themselves from their darker brethren... Hurston dramatizes the fact that color prejudice takes many forms. In effect, the dramatic twist Hurston portrays is twofold: both John and Emma are "color struck," albeit in opposing and unpredictable ways. Emma is drawn to light skin (notably, after her relationship with John fails, she presumably has a sexual relationship/encounter with a white man, resulting in the birth of a "very white girl"), while John exhibits colorconsciousness in his preference for dark-skinned women (after the breakup, he consciously seeks out a darker-skinned wife that "was jus' as much" like Emma as possible.

\section{Conclusion:}

In her works, Hurston addresses the 1920 s and 1930 s audience . In these decades, the social, political, and religious Afro-Americans movements were at their peak. While many writers of the Harlem Renaissance tended to address the discrimination and the oppression of whites to their people, Hurston focuses on the discrimination and the oppression within her own race. In order to achieve a complex portrayal of Afro-Americans as humans, she focuses on the often disregarded voice of the black female. Her works are imbued with women seeking to express their emotions and experiences, women searching for their place in both the Afro- American and the American nation. Hurston's works thus provide a channel for promoting the cause of black women's empowerment and resistance to decades of male dominance, be it black or white, over their bodies and womanhood. Hurston is sure to describe her characters skin color, and the ways that skin color, in her characters' eyes, relate to prestige and accomplishment. Emma's tale is a gloomy one, because instead of empowerment, her consciousness about her skin color brings fear, anxiety, depression and separation. Hurston seems to suggest in Color Struck that such anxiety over the body image and color-consciousness is not the path to take. In other words, being color struck is not the way to go in Hurston's opinion.

\section{References}

Banks, T. L. (2000). "Colorism: A Darker Shade of Pale".UCLA Law Review. Symposium Race and the Law at the Turn of the Century 47: 1705-1885.

Beneš , J.(2011). Discourse on Sexuality in the Works of Zora Neale Hurston. Masaryk University: Faculty of Arts.

Bengal, R. (April 18, 2010)."Following the dust tracks: Touring Florida through the eyes of Zora Neale Hurston." The Washington Post, www.washingtonpost.com 
Bower, M. G. (Winter, 2004). "Color Struck" under the Gaze: Ethnicity and the Pathology of Being in the Plays of Johnson, Hurston, Childress, Hansberry, and Kennedy. African American Review. Vol. 38, No. 4, pp. 729-731.

Butterworthy, S.( 11September 2006). “Women and Literature: Zora Neale Hurston.”Oxford University Press. $<$ http://blog.oup.com/oupblog/2006/og/women_and_liter.html>.

Carpenter, F. C.(2009)."Addressing "The Complex"-ities of Skin Color: Intra-Racism and the Plays of Hurston, Kennedy, and Orlandersmith." Theatre Topics 19.1, 15-27.

Case, Sue-Ellen. (October 1985). Classic drag: The greek creation of female parts. Journal of Dramatic Theory and Criticism. viii(2) pp.317-327.

Cortez, M. "A Literary Analysis of "How It Feels to Be Colored Me"

http://teachmix.com/amlit/reader/south/cortez.html

Crawford, M. N.(2008). Dilution Anexiety and the Black Phallus.Ohio State University.

Farsides, T. L. (2012). Social-esteem, social comparison and discrimination: A Reappraisal and Development of Tajfel-S Social Identity Theory. University of London.

Herring, C.(2004). Skin deep: How race and complexion matter in the

"color- blind" era . Urbana and Chicago: University of Illinois at Chicago, 1-21.

Hurston ,Z. N. (1995). Dust Truck on the Road .New York: Harper press.

(2008). Color Struck, in Zora Neal Hurston Collected Play, Jean Lee Cole and Charles Mitchell, eds. ( New Jersey and London: Rutgers University Press.

Jones, S. L.(2009). Critical Companion to Zora Neal Hurston; A Literary Reference to her life and Work. Facts On File: New York.

Konzett, D. C.(2002). Ethnic Modernism, Anzia Yezierska, Zora Neal Hurston, Jean Rhys, and the Aesthetics of Dislocation. U.S.A.: Palgrave Macmillan.

Laníková, L.(2007). Zora Neale Hurston Rediscovered. Masaryk University. Brno, 2007.

North, M.(1994). The Dialect of Modernism: Race, Language, andtwentieth-Century Literature. New York: oxford university press. 1994.

"On Dark Girls," The Association of Black Psychologists, p.1 static.oprah.com/pdf/dark-girls.pdf

Oslica, A. Race, Class, Gender \& Property in Women's Writing of the Harlem Renaissance.

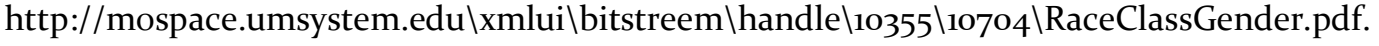

Patterson,T. R. (2005). Zora Neal Hurston and a History of Southern

Life . U.S.A .,Temple University press.

Rose, H.(1989). Women's work: Women's knowledge. In Juliet Mitchell \&Anne Oakley (eds.).What is feminism . London: Basil Blackwell, 161-183. 